\title{
THE CUSTODY REQUIREMENT AND TERRITORIAL JURISDICTION IN FEDERAL HABEAS CORPUS: WORD v. NORTH CAROLINA
}

Prisoners Word, Matthews, and Williams were serving sentences imposed upon them in and by the Commonwealth of Virginia. During the course of their respective incarcerations, each had been returned to North Carolina to stand trial for another offense, convicted, sentenced, and sent back to Virginia to complete the remainder of his sentence there. North Carolina authorities lodged a detainer against each of the three, so that he would be available to serve the North Carolina sentence upon completion of the Virginia confinement.

The prisoners sought the remedy of federal habeas corpus to challenge the constitutionality of the sentences to be served in North Carolina upon completion of the Virginia commitments. ${ }^{1}$ Williams sought relief in the United States District Court for the Eastern District of North Carolina, while Word and Matthews brought their actions in the Eastern District of Virginia.

The prisoners' petitions were dismissed by the respective district courts in which they were filed. ${ }^{2}$ On appeal, the Fourth Circuit Court of Appeals consolidated the cases to decide the question "whether . . . federal habeas corpus provides a present remedy for a state prisoner seeking to attack, on constitutional grounds, a conviction in another state which underlies a detainer filed with his keeper." 3 Rejecting the alternative that the prisoners postpone any remedy until they have completed service of their Virginia sentences and have been delivered into the physical custody of a North Carolina warden, the court held, in Word v. North Carolina, ${ }^{4}$ that federal habeas corpus did provide a present remedy for the state prisoners. In light of the Supreme Court's affirmance of Peyton v. Rozere, Chief Judge Haynsworth, writing for the majority, again ${ }^{6}$ inveighed against the "custody" requirement of

1 A state prisoner, seeking federal habeas corpus under 28 U.S.C. $\$ 2241$ (1964), must first meet the requirements of $\$ 2254$ by demonstrating that he has "exhausted the remedies available in the courts of the State, or that there is either an absence of available State corrective process or the existence of circumstances rendering such process ineffective to protect the rights of the prisoner." 28 U.S.C. \$2254 (1964). See Fay v. Noia, 372 U.S. 391 (1963) ; 113 U. PA. L. Rev. 1303 (1965). See generally Lay, Problems of Federal Habeas Corpus Involving State Prisoners, 45 F.R.D. 45 (1969); Reitz, Federal Habeas Corpus: Impact of an Abortive State Proceeding, 74 HARv. L. REV. 1315 (1961).

2 Word v. North Carolina, 406 F.2d 352, 355 (4th Cir. 1969).

$3 I d$. at 353.

4 This argument was drawn from the essence of the "prematurity doctrine" set forth in McNally v. Hill, 293 U.S. 131 (1934). But see Peyton v. Rowe, 391 U.S. 54 (1968) (overruling $M c N$ ally).

5391 U.S. 54 (1968).

- See Rowe v. Peyton, 383 F.2d 709 (4th Cir. 1967) aff'd, 391 U.S. 54 (1968). For commentary on the Roze decision, see 9 WM. \& MARY L. REv. 887 (1968). 


\section{federal habeas corpus. ${ }^{7}$}

Another question, however, remained to be considered: In which district court would the petitions be properly filed? The Fourth Circuit ruled that the proper forum would be found in the sentencing state, presumably in the district within that state where a proper respondent would be available. The district wherein the prisoner is confined, "where permissible, [would be] infrequently preferable." 8 As a result, the Fourth Circuit affirmed the Virginia district court's dismissal of two petitions, ${ }^{9}$ while it vacated the dismissal of the third petition, remanding it to the North Carolina district court for further proceedings. ${ }^{10}$

\section{The Custody Reguirement}

\section{A. Background}

The availability of federal habeas corpus to a state prisoner seeking to challenge the constitutionality of his detention has recently been substantially expanded. ${ }^{11}$ Deeply rooted in the common law, ${ }^{12}$ the writ has broadened in scope, in keeping with the current revolution in criminal procedure. ${ }^{13}$

7 Under facts strikingly similar to those of the principal case, the Fourth Circuit, in 1960, denied the application of a state prisoner in Ohio seeking relief in the Eastern District of Virginia from the effect of a detainer filed against him by the Virginia Parole Board. As a basis for his contention that the detainer was unlawful, the Ohio prisoner alleged that the earlier Virginia conviction was void on constitutional grounds. The court then held that the Virginia Parole Board had neither actual nor constructive custody of the petitioner, and thus the action could not be brought in Virginia. Whiting v. Chew, 273 F.2d 885 (4th Cir.), cert. denied, 362 U.S. 956 (1960). It may be assumed that the Fourth Circuit considers this case overruled.

$8406 \mathrm{~F} .2 \mathrm{~d}$ at 355 . Where the conviction in the other state underlies a finding of recidivism and the imposition of a longer sentence, the district court of the confining state would have jurisdiction, because: "A state may properly be called upon to defend its own judgment even though it is predicated upon a foreign conviction." Id. at 357 n.6.

$9 \mathrm{Id}$. at 361 .

10 Id. at 362 . Since Williams had never availed himself of North Carolina's postconviction remedies (because the petition would not be heard until he was placed in actual custody and serving his North Carolina sentence). Williams was obliged to wait until North Carolina reappraised "its position in the presence of the new atmosphere created by Peyton v. Rowe." Id. at 361. This position seems ironic where prompt adjudication of constitutional claims has been the stated policy.

The dismissal of the petitions of Word and Matthews also seems to be harsh treatment in the face of the desired policy. "At the very least, the prisoners should be afforded an opportunity to amend, instead of having their petitions dismissed." Id. at 365 (Sobeloff, J., dissenting in part). However, since new petitions could be filed without delay in North Carolina, the prisoners were not prejudiced by the dismissal. (1963).

11 See, e.g., Fay v. Noia, 372 U.S. 391 (1963); Townsend v. Sain, 372 U.S. 293

12 For a discussion of the historical approach to habeas corpus, see D. MEADOR, Habeas Corpus and Magina Carta (1966); Oaks, Legal History of the High Court - Habeas Corpus, 64 MICH. L. REv. 451 (1966).

13 See generally Meador, The Impact of Federal Habeas Corpus on State Trial Procedure, 52 VA. L. REv. 286 (1966); Wilson, Federal Habeas Corpus and the State Contr Criminal Defendant, 19 VAND. L. Rev. 741 (1966). The federal writ of habeas corpus has become primarily a means by which one court of general jurisdiction exercises postconviction review over the judgment of another court of like authority. See Reitz, Federal Habeas Corpus: Postconviction Remedy for State Prisoners, 108 U. PA. L. Rev. 461 (1960). 
The availability of the "great writ" has been limited, however, by the traditional requirement that the petitioner be "in custody" under the sentence which he desires to challenge. ${ }^{14}$ Section 2241 (c) (3) of title 28 of the United States Code incorporates this common law requirement: "The writ of habeas corpus shall not extend to a prisoner unless ... [h] e is in custody in violation of the Constitution or laws or treaties of the United States . . ."15 Until recently, ${ }^{16}$ the term "in custody" was interpreted, according to its meaning at common law, to require both that the petitioner be restrained currently under the challenged sentence and, as a corollary, that the effect of the writ be to release the prisoner from that restraint. ${ }^{17}$

The Supreme Court's decision in Peyton v. Rowe ${ }^{18}$ took much of the vitality out of this traditional custody interpretation. Persuaded in part by the common usage of "custody" to describe the total time imprisoned, and in part by the fact that the sentences would be lumped together for parole purposes, the Supreme Court struck down the "prematurity doctrine" of McNally v. Hill ${ }^{19}$ and broadly held that "a prisoner serving consecutive sentences is 'in custody' under any one of them for the purposes of section 2241 (c) (3)." 20 He may, therefore, invoke federal habeas corpus to challenge the constitutionality of a sentence to be served in the future. The Peyton Court said that two considerations led to overruling $M c N a l l y$ : first, "to the extent that the rule of $M c N a l l y$ postpones plenary consideration of issues by the district courts, it undermines the character of the writ of habeas corpus as the instrument for resolving fact issues not adequately developed in the original proceedings"; ${ }^{21}$ and second, an application of McNally in the context of the Peyton case would be at odds with "a principal aim of the writ," 22 which is "to provide for swift judicial review of alleged unlawful restraints on liberty." 23

14 For a generally critical treatment of the custody requirement prior to the Supreme Court's decision in Peyton v. Rozere, see Note, Habeas Corpus and the Prematurity Rule, 66 Colom. L. Rev. 1164 (1966); Note, Habeas Corpus, Custody and Declaratory Judgment, 53 VA. L. Rev. 673 (1967); 65 MICE. L. REv. 172 (1966).

Historically, habeas corpus was not available to petitioners who were not subject to an immediate and confining restraint on their liberty. See Collings, Habeas Corpus for Convicts-Constitutional Right or Legislative Grace?, 40 CALIF. L. REv. 335, 335-38 (1952).

1528 U.S.C. $\$ 2241$ (c) (3) (1964) (emphasis added).

16 See, e.g., Rowe v. Peyton, 383 F.2d 709 (4th Cir. 1967), aff'd, 391 U.S. 54 (1968); Williams v. Peyton, 372 F.2d 216 (4th Cir. 1967); Martin v. Virginia, 349 F.2d 781 (4th Cir. 1965).

17 See note 14 supra.

18391 U.S. 54 (1968).

19293 U.S. 131 (1934).

20391 U.S. at 67.

$21 \mathrm{Id}$. at 63 .

22 Id.

23 Id. 
In the principal case, the Fourth Circuit seized upon the newborn Peyton doctrine ${ }^{24}$ as compelling the further result that federal habeas corpus be available to prisoners attacking not consecutive sentences but unserved sentences imposed by another state. The $W$ ord court offered two basic justifications for its holding that these unserved sentences satisfied the custody requirement of section 2241 . First, the concomitant detainer overshadowing each petitioner has sufficient impact on his current imprisonment to allow construction of a "dual authority" fiction in which petitioners are deemed to be in custody under the future sentence. This impact is felt in the length of the immediate sentence, since petitioners are less likely to be released on parole due to the detainers, ${ }^{25}$ and in the nature of the present confinement, since prisoners under detainers suffer a higher degree of security and scrutiny in their incarcerations than normal prisoners. ${ }^{26}$

The second justification rests on policy grounds. The Supreme Court strongly advanced the policy in Peyton that it is desirable to have such constitutional claims adjudicated promptly in order to avoid the probable corrosion of evidence and memories by the passage of several years, thus impeding any further evidentiary determination that might become necessary.

From these two justifications the Fourth Circuit's extension of Peyton follows both logically and as a matter of policy. The court's explication, however, needs further analysis.

\section{B. Present Impact of the Detainer: Effect on Length of Sentence}

In Peyton, the Supreme Court took special note of the fact that the petitioner's parole eligibility under a Virginia statute was to be calculated on the basis of the aggregate total of his consecutive sentences. ${ }^{27}$ Because of this emphasis, the Fourth Circuit felt constrained to say that detainers lodged against the present petitioners also operated adversely in parole considerations. This parallel is not perfect. Unlike the restraint in Peyton, the effect on parole eligibility in Word is not compelled by statute. Under the Virginia statute, ${ }^{28}$ there is no mention

24 Even before the Peyton decision, at least one commentator believed that it was not material where the prisoner was actually confined so long as the custodian was within the power of the court. D. MEADOR, supra note 12, at 42 .

25406 F.2d at 354. Prisoners are selected for parole primarily on the basis of the parole board's evaluation of the individual prisoner's prospects for re-assimilation into society. For a thorough discussion of the factors in parole selection, see DRESSLER, Practice and Theory of Probation and Parole 106-20 (2d ed. 1969). See also Newman, Sourcebook on Probation, Parole and Pardons (3d ed. 1968).

26406 F.2d at 354. This argument has also been advanced in other contexts. E.g., Lawrence v. Blackwell, 298 F. Supp. 708 (N.D. Ga. 1969) (federal prisoners seeking declaration that restrictions imposed upon them because of state detainers violated their constitutional rights) ; Gregory v. Page, 289 F. Supp. 316 (E.D. Okia. 1968) (federal prisoner seeking injunctive relief). See generally Note, The Detainer: A Problem in Interstate Criminal Administration, 48 ColUM. L. Rev. 1190 (1948); Note, Detainers and the Correctional Process, 1966 WASH. U.L.Q. 417.

27391 U.S. at 64-65.

28 VA. CODE ANN. §53-251 (1967). 
that a future sentence to be served in another state figures in the calculation of parole eligibility.

Nevertheless, although statutory compulsion is absent, the detainer may well have a subtle, indirect impact on parole selection. In evaluating an application for parole, the parole board considers the prisoner's prospects for a successful reentry into society. ${ }^{29}$ A prisoner against whom a detainer has been lodged will not reenter society upon release. Hence, any evaluation of his application involves speculation about the prisoner's distant, uncertain future which the parole board may be unwilling to make. Instead, the board will generally, like the congressional committee faced with an unpopular bill, pigeonhole the parole application. ${ }^{30}$

In addition to reducing the prisoner's chance to obtain parole, the detainer reflects an unfortunate plight brought about by concurrent state sentencing powers, which generally cause multi-jurisdictional offenders to serve longer total sentences than they would have had to serve had they committed the crimes within any one state. Each state tends to extract full satisfaction for the offenses against it, ignoring the prisoner's criminal liability to other jurisdictions. Hypothetically, if only one court were to try the multi-state offender for all crimes, it could more easily put the different offenses in perspective, notwithstanding the fact that they were committed in more than one state, and prescribe sentence with a view to both the amount of punishment necessary and the possibility of rehabilitation. ${ }^{31}$

On a practical level, therefore, the detainer and the future sentence tend to create restraints on a prisoner's liberty. Because they increase the time to be served on his aggregate sentences, and because they reduce the possibility of his parole, the prisoner finds himself facing prolonged incarceration when he might otherwise be released.

\section{Present Impact of the Detainer: Nature of the Confinement}

Even though the Peyton Court was concerned only with the effect of the future sentence upon the duration of the prisoner's confinement, the Word court further considered the detainer's interference with the nature of that confinement. ${ }^{32}$ The court pointed out that the warden was required to jail the prisoner with a greater degree of security than the Virginia commitment alone demanded. ${ }^{33}$ Whether a prisoner has

29 DRESSLER, supra note 25 , at 100-04.

301966 WASH. U.L.Q., supra note 26, at 421-22. See generally Note, Habeas Corpus-The Nature of Restraint in Parole and Probation, 40 CoNN. B.J. 473 (1966). 311966 WASH. U.L.Q., supra note 26, at 423; see Perry, Effect of Detainers on Sentencing Policies, 9 FED. Probation no. 3, July-Sept., 1945, at 11-12.

32406 F.2d at 355 .

33 This requirement, however, stems from the executive branch of the government; for the administration of prisons falls under the purview of neither the legislative nor the judicial branches, and the courts "will only intervene in cases of extreme hardship." Lawrence v. Blackwell, 298 F. Supp. 708, 714 (N.D. Ga. 1969) (dictum). See, e.g., Startti v. Beto, 405 F.2d 858 (5th Cir. 1969) (per curiam). 
an enforceable right, however, to have his "level of custody" modulated in response to such extrinsic factors as the presence or absence of detainers is a question still unanswered. ${ }^{34}$ Generally speaking, prison authorities have made the judgment, based upon experience, that prisoners with detainers should be treated more restrictively. ${ }^{35}$ Even if the judgment of prison authorities seems to be at odds with modern correction and rehabilitation theories, the courts traditionally will not even consider intervening, except in cases of cruel or unusual punishment. $^{36}$

To say that the fact that the prisoner is subjected to a higher level of confinement because of the detainer does not, by itself, satisfy the custody requirement is not to say that this consideration, when linked with its indirect impact upon the duration of the prisoner's jail term, should not be given weight in applying Peyton. The prisoner under shadow of a detainer, precluded from attaining trusty status ${ }^{37}$ and from gaining access to the constructive, useful jobs at the prison, has little opportunity to do the kinds of things that develop a good prison record or that demonstrate his readiness for return to the outside. Hence, even

34 Bui see Gregory v. Page, 289 F. Supp. 316 (E.D. Okla. 1968) (state's detainer warrant lodged against a prisoner did not deprive him of his constitutional rights by making him ineligible for parole or trusty status). But cf. Lawrence v. Blackwell, 298 F. Supp. 708 (N.D. Ga. 1969) (state's continued failure to make good-faith efforts to secure federal prisoners a speedy trial on state charges must not result in continuance of prison restrictions flowing from those charges).

35 As a former director of the United States Bureau of Prisons has stated, those "prisoners with detainers are evaluated individually but there remains a tendency" to consider them escape risks and assign them accordingly." Bennett, The Last Full Ounce, 23 FED. Probation, June 1959, at 20, 21, quoted in Lawrence v. Blackwell. 298 F. Supp. 708, 713 (N.D. Ga. 1969). See Hess v. Blackwell, 409 F.2d 362 (5th Cir. 1969); United States v. Candelaria, 131 F. Supp. 797, 805 (S.D. Ca1. 1955).

${ }^{36}$ E.g., Startti y. Beto, 405 F.2d 858 (5th Cir. 1969). A Texas prisoner was caught acting as a lookout for other inmates who were involved in a poker game. Placed in solitary confinement on a diet of bread and water for nine days, the prisoner sought relief through a mandamus action based upon the Civil Rights Act of 1954, 42 U.S.C. $\$ 1983$ (1965). The court denied relief, holding that: "The petitioner's complaint does not rise to the constitutional level but deals with matters of prison discipline solely the concern of the state." Id. at 859 . See United States ex rel. Lee v. Illinois, 343 F.2d 120 (7th Cir. 1965); United States ex rel. Knight v. Ragen, 337 F.2d 425 (7th Cir. 1964), cert. denied, 380 U.S. 985 (1965); Tabor v. Hardwick, 224 F.2d 526 (5th Cir. 1955), cert. denied, 350 U.S. 971 (1956).

Competing with the courts' understandable reluctance to interfere with internal prison administration, however, is the growing "realization that certain constitutional guarantees protect even convicts.. "Equal Protection and Prison-to-Hospital Transfers: United States ex rel. Schuster v. Herold, 118 U. PA. L. REv. 410 (1970). The idea that a prisoner is completely without any rights or remedies has met with increasing repudiation by the courts; but the courts have not yet abandoned the general rule of noninterference; and complaints directed toward the warden's evaluation of a prisoner's security risk will be scrutinized usually by a strict "cruel and unusual punishment" standard; see Graham, When a Convict Becomes a Plaintiff, N.Y. Times, Jan. 4, 1970, $\$ 4$ (Week in Review), at 6 . See genterally Note, Constitutional Rights of Prisoners: The Developing Laze, 110 U. PA. L. Rev. 985, 995-1006 (1962). But cf. United States $e x$ rel. Schuster v. Herold, 410 F.2d 1071 (2d Cir.), cert. denied, 90 S. Ct. 81 (1969); Equal Protection and Prison-to-Hospital Transfers: United States ex rel. Schuster v. Herold, 118 U. PA. L. REv. 410 (1970).

$37 \mathrm{An}$ inmate who has special privileges and who lives and works in and about the institution under less restrictive conditions is commonly called a trusty by prison authorities. 
if the parole board looks at this prisoner's parole application, ${ }^{38}$ it is not likely to act favorably because of his unimpressive record.

\section{The "Dual Authority" Fiction: Rationalization for a Policy Decision}

Even though the detainer and the future sentence clearly affect the prisoner's present confinement, it remains to be explained why he can be deemed to be "in custody" now, in order to have standing to invoke federal habeas corpus under section 2241. Since the prisoner is not attacking his present conviction and sentence, this explanation must involve the peculiar situation in which the prisoner, legally confined, maintains that he is illegally "in custody."

To solve this problem, the Fourth Circuit attempted to link the detainer and a proper North Carolina respondent with the petitioner's immediate confinement by adopting the "dual authority" fiction. The custody requirement is thus met by the assertion that the Virginia warden's authority to hold a prisoner against whom a detainer has been filed is "clearly dual." 39 However, except as a useful fiction, this proposition has no basis in fact: the prisoner is not being held under the legal authority of North Carolina, for the detainer does not constitute authority to restrain a prisoner; it is merely a request to hold him temporarily, and the jailer gives it only what effect he chooses. ${ }^{40}$ The court supports its fiction with the statement that " $[t]$ he prisoner has no hope of release until both authorizations are ended . . . " 41 but it is unlikely that the warden would keep a prisoner whose sentence term has ended if the authorities who had lodged the detainer did not claim him in a few days.

Although the theory of the court may be unrealistic, the fiction's use can be supported. While the detainer does not attach to the prisoner as legal authority for his confinement, it does have an impact on his present custody. ${ }^{42}$ Thus, to the extent that the North Carolina detainer and unserved sentence affect the duration of the petitioner's Virginia commitment, there is practical significance in the dual authority concept.

The more persuasive reason, however, for employing the dual authority fiction is the policy expressed in Peyton $v$. Rowe. ${ }^{43}$ Use of

38 See text accompanying notes $29-30$ supra.

39406 F.2d at 355 .

40 See, e.g., Ashley v. Washington, 394 F.2d 125 (9th Cir. 1968), in which the court stated:

[s]o far as we can tell, the detainer or warrant issued by the State of Washington does not purport to have any extraterritorial effect, assuming that somehow it could. If it has any effect in Florida, that is only because Florida chooses to give it that effect.

Id. at 126. See Whiting v. Chew, 273 F. 2d 885 (4th Cir. 1960) (opinion by Sobeloff, C.J.). But cf. Sloope v. Peyton, 290 F. Supp. 741 (E.D. Va. 1968).

41406 F.2d at 355.

42 See notes 30-31 supra.

$\$ 3391$ U.S. 54, 59, 63 (1968). 
the fiction provides an immediate forum for the prompt adjudication of the petitioner's constitutional claims, which might otherwise be denied because of the niceties of the custody rule. Since a factual hearing on issues not developed in the challenged proceedings and the ordering of a new trial are present possibilities, "custody" obstacles placed in the way of timely resolution of such claims would tend to jeopardize the prisoner's opportunity to vindicate his rights; for the passage of time inevitably means that evidence will be lost or destroyed, memories will fade, and witnesses will die. ${ }^{44}$ Acceptance of the dual authority fiction, therefore, helps to disperse some of the confusion enshrouding searches for "restraints on liberty" in the case of prisoners, legally jailed, attempting to attack the constitutional validity of an unserved sentence imposed by another jurisdiction.

\section{The Problem of Territorial Jurisdiction}

Allowing prisoners to attack the constitutional validity of an unserved sentence imposed by another jurisdiction, a possibility existing only since Peyton $v$. Rowe was decided in 1968, raises the issue of which district courts afford a proper forum. Looking only to the dual authority fiction, either the district of confinement or a district in the sentencing state, or both, could be deemed to be a proper forum. The Word court, however, concluded that generally the proper federal forum is in the sentencing state. The major problem in determining the answer to this territorial puzzle stems from the ambiguity found in the statutory language. Section 2241, which confers the power to issue the writ, provides: "Writs of habeas corpus may be granted by the . . . district courts . . . . within their respective jurrisdictions." 45

The Supreme Court, in Ahrens v. Clark, ${ }^{46}$ construed this language $^{47}$ as a territorial limitation imposed by Congress on the power to issue the writ. The Court held that a federal district court lacks jurisdiction to issue a writ of habeas corpus if the person detained is not within the territorial jurisdiction of the court when the petition is

14406 F.2d at 354; 53 VA. L. REv., supra note 14, at 675.

4528 U.S.C. $\$ 2241$ (a) (1964) (emphasis added).

4335 U.S. 188 (1948). Deportation orders had been issued by the Attorney General of the United States, directing the removal of some 120 Germans under the authority of a presidential proclamation. Petitions for habeas corpus were filed with the District Court for the District of Columbia, where the Attorney General was located, while the German petitioners were being held at Ellis Island, New York, awaiting removal. The respondent moved to dismiss, because the petitioners were outside the territorial confines of the District of Columbia. The petitioners argued that, although confined in New York, they were subject to the custody and control of the Attorney General. The district court dismissed the petitions, the court of appeals dismissed the appeal, and the Supreme Court affirmed.

47 Although the language construed by the Ahrens Court was that of the Act of Feb. 5,1867 , ch. 28,14 Stat. 385 , the language of its successor statute, 28 U.S.C. $\$ 2241^{\prime}(1964)$, is substantially the same. See 406 F.2d at 362-63 n.4 (Winter, J., dissenting); Duncan v. Maine, 295 F.2d 528 (1st Cir. 1961), cert. deried, 368 'U.S. 998 (1962). 
filed. ${ }^{48}$ The Court said :

Although the writ is directed to the person in whose custody the party is detained, . . . the statutory scheme contemplates a procedure which may bring the prisoner before the court. . . . It would take compelling reasons to conclude that Congress contemplated the production of prisoners from remote sections, perhaps thousands of miles from the District Court that issued the writ. The opportunities for escape afforded by travel, the cost of transportation, the administrative burden of such an undertaking negate such a purpose. These are matters of policy which counsel us to construe the jurisdictional provision of the statute in the conventional sense, even though in some situations return of the prisoner to the court where he was tried and convicted might seem to offer some advantages. ${ }^{49}$

Although the Ahrens court was not concerned with the peculiar problem of multi-state offenders, nor with the need to forge an adequate remedy for those challenging future sentences across state lines, ${ }^{\text {s0 }}$ the lower courts faced with this problem have generally followed the Ahrens rule by requiring the presence of both the petitioner and the jailer within the court's territorial jurisdiction. ${ }^{51}$ A departure from the spirit of the Ahrens rule has occurred in cases where the petitioner was detained outside the jurisdiction of any district court and the official authorizing the detention was within the court's territorial reach. ${ }^{52}$

48 Except for the decision in the principal case, the courts of appeals have applied the broad Ahrens language in considering cases on point with the principal case. George v. Nelson, 410 F.2d 1179 (9th Cir. 1969); United States ex rel. Van Scoten v. Pennsylvania, 404 F.2d 767 (3d Cir. 1968) ; Ashley v. Washington, 394 F.2d 125 (9th Cir. 1968); Booker v. Arkansas, 380 F.2d 240 (8th Cir. 1967); Duncan v. Maine, 295 F.2d 528 (1st Cir. 1961), cert. denied, 368 U.S. 998 (1962); Whiting v. Chew, 273 F.2d 885 (4th Cir.), cert. denied, 362 U.S. 956 (1960) (alternative holding) (probably overruled by the principal case; note 7 supra).

49 Ahrens v. Clark, 335 U.S. 188, 190-91 (1948). The Court's practical considerations lose much of their force when viewed in light of the modern state and federal practice of transporting prisoners across state lines to stand trial in other jurisdictions and then transporting them back to continue service of their current sentences.

50406 F.2d at 360 (distinguishing Ahrens).

51 See cases cited in note 48 supra. See also Halprin v. United States, 293 F. Supp. 1186 (S.D.N.Y. 1968); Lewis v. Connett, 291 F. Supp. 583 (W.D. Ark. 1968). But see Sanders v. United States, 297 F. Supp. 375 (N.D. Ga. 1968) (dictum).

The Ahrens rule has been cited in other contexts as well, e.g. McDowell v. Sacramento Local Bd. Group, Bds. 21, $22 \& 23,264$ F. Supp. 492 (E.D. Cal. 1967) (petitioner attacking proceedings of local and state appeal boards in induction transfer) (alternative holding); Powell v. Langlois, 204 F. Supp. 91 (E.D.N.C. 1962) (prison escapee in another state awaiting extradition).

52 The Ahrens Court had specifically reserved this question, 335 U.S. at 192 n.4. See, e.g. Burns v. Wilson, 346 U.S. 137 (semble), rehearing denied, 346 U.S. 844 (1953) (per curiam) (separate opinion by Frankfurter, J.); Day v. Wilson, 247 F.2d 60 (D.C. Cir. 1957). See also United States ex rel. Toth v. Quarles, 350 U.S. 
Recently, however, a conflict in the circuits has developed over the effect to be given Ahrens. In the instant case, the Fourth Circuit went well beyond Ahrens in ruling that a state prisoner who brings an attack on a future sentence in another state must file his petition in the federal forum where the sentencing court is to be found. However, the Ninth Circuit in George v. Nelson ${ }^{53}$ cited Ahrens in deciding that a petitioner confined in California, but also under a North Carolina detainer, could properly challenge the North Carolina sentence in the confining district. The George court noted that its result was not necessarily inconsistent with $W$ ord, since $W$ ord did not categorically rule out the district of confinement as a proper forum. Word only said, continued George, that the district of confinement "where permissible [is] infrequently preferable." Despite this language in George, it is quite clear that the George and $W$ ord holdings are, for the most part, inconsistent: Word held that the district of confinement was not a proper forum; and, in an analogous situation, George held that it was.

Thus, it remains unclear whether a prisoner wishing to bring habeas corpus to challenge a future sentence underlying a present detainer should file his suit in the confining or sentencing state. $\mathrm{He}$ can point to authority for either choice. The uncertainty present in this area calls for a reexamination of the rules for forum selection in habeas corpus cases; wooden application of the Ahrens doctrine may not provide the best results.

\section{A. Section 2241: The Requirement That Courts Issue Writs "Within Their Respective Jurisdictions"}

The Ahrens Court held that the district court's jurisdiction depended upon the presence of the habeas corpus petitioner within its territorial bounds. However, application of the Ahrens rule to the Word case is not compelled by that holding. The possibility that a habeas corpus petition could be brought by a state prisoner to challenge a future sentence of a foreign state has existed only since the Court's decision in Peyton v. Rowe. Ahrens did not face that problem. The

11 (1955) (by implication); Hirota v. MacArthur, 338 U.S. 197, 202-03 (1949) (Douglas, J., concurring). But cf. Carbo v. United States, 363 U.S. 611 (1961) (writ of habeas corpus ad prosequendum different from the "Great Writ") ; see Barber $v$. Page, 390 U.S. 719 (1968) (writ of habeas corpus ad testificandum).

53410 F.2d 1179 (9th Cir. 1969). The Supreme Court has recently granted certiorari in the George case to decide these questions:

Is warden of California prison proper party respondent in one of his inmates' federal habeas corpus attack upon future North Carolina sentence, pursuant to which detainer has been lodged against inmate? . . Does California federal court have jurisdiction over habeas corpus petition brought by California prisoner attacking a future North Carolina sentence that has led to the lodging of a detainer against prisoner?

38 U.S.I.W. 3205 (U.S. Dec. 9, 1969). See Hearne v. Washington State Parole Bd., 300 F. Supp. 536 (E.D. Wash. 1969) (court did not have territorial jurisdiction to entertain Kansas state prisoner's habeas petition seeking to challenge unserved Washington state sentence). 
Court there was dealing with petitioners confined under the express authority of the Attorney General of the United States by a warden who was an United States official. Thus, by requiring that the petitioners bring suit in the confining district, the Court was merely fitting the fact situation into the traditional habeas corpus pattern calling for the prisoner to file the action against the official confining him. This requirement presented no particular problem in Ahrens, because the actual confining official was clearly under the authority of the local federal jurisdiction responsible for the restraint. In the fact pattern presented by $W o r d$, however, the official actually confining the petitioner was not under the authority of the foreign jurisdiction responsible for the challenged sentence; authority for his confinement derived from the Commonwealth of Virginia under a conviction and sentence which were admittedly legal. This posture presented problems which could not have been anticipated by Congress in enacting the habeas corpus statute, nor by the Ahrens Court in construing it. The ambiguous meaning of "within their respective jurisdictions," therefore, might justifiably be taken beyond the Ahrens holding.

A statutory interpretation more consistent with the increasing availability of federal habeas corpus would seek to ease the geographic constraints imposed by a broad reading of Ahrens. While a territorial limitation on the judicial power to issue writs of habeas corpus was doubtless intended by Congress, there is no indication that a limitation was contemplated that was as severe as that articulated in the Ahrens opinion. Congress, chiefly concerned with limiting federal courts' power to issue process against jailers in other states, was reluctant to extend the reach of a district court's process beyond state boundaries. ${ }^{54}$ However, where the "confining authority" is present within the territorial jurisdiction of the court issuing the writ, the abuse which the words, "within their respective jurisdictions," were designed to remedy would not be possible. Thus, a more sensible interpretation of section 2241 would require only the presence within the district of a proper respondent to the habeas corpus petition, ${ }^{55}$ a respondent who caused the allegedly illegal sentence to bear upon the petitioner in some fashion.

Construed in this manner, the statute presents no jurisdictional barrier to either the Word or George result. Obviously, in Word, the North Carolina authorities responsible for petitioner's future sentence and the detainer attached to his present sentence were located in the North Carolina District. In George, the confining warden also was a proper respondent, assuming that the dual authority fiction satisfies

64 Cong. Globe, 30th Cong., 2d Sess. 730, 790 (1849). The legislative history speaks in terms of preventing courts from compelling the appearance of out-of-state prisoners. However, this compulsion may only be effectuated by issuing process against the out-of-state jailer.

55 Requiring only a proper respondent is more in line with traditional habeas corpus concepts. See Ahrens v. Clark, 335 U.S. 188, 193-98 (1948) (Rutledge, J., dissenting); Comment, 44 N.Y.U.L. REv. 845, 851-52 (1969). 
the custody requirement of section 2241 , since he was giving effect to the allegedly illegal detainer.

\section{B. Evaluation of the Alternatives}

Although the sentencing state and the state of confinement both afford jurisdictionally appropriate forums for a habeas corpus challenge of a future sentence, it is possible to make some evaluation of the relative convenience of each forum. The policy of expanding the availability of the writ impels the conclusion that the Word approach is preferable, and that the petition should be filed in the sentencing state. The writ can then be employed most effectively to achieve adequate relief and prompt adjudication of petitioner's claim.

The $W$ ord court correctly perceived that a habeas corpus petition, challenging a future sentence and brought in the state presently confining the petitioner, would face a serious obstacle: there are no North Carolina officials subject to service of process in Virginia. Therefore, unless North Carolina officials appear voluntarily in Virginia, the court will lack personal jurisdiction over them. Hence, if the court desired to grant full relief, it would be forced to invalidate a North Carolina sentence on the basis of the appearance of the Viriginia warden.

This situation presents two problems. First, without service of sentencing authorities, the court might not assume jurisdiction to consider the conviction. The judisdictional requirement could be met technically by deeming the Virginia warden a North Carolina agent pursuant to the dual authority concept. However, practical questions would still abound concerning the desirability of permitting a district court to invalidate a foreign state's conviction on the basis of what is likely to be a half-hearted defense..$^{56}$

Furthermore, principles of comity suggest that the district courts in the confining district would be well advised to refrain from adjudicating the merits of claims. Federal judges in the sentencing state are probably better qualified to evaluate local convictions due to their familiarity with the local criminal process. Without the appearance of sentencing authorities, a hearing in the confining state would be lampered by the fact that confining authorities, attempting to defend the conviction, would start out with a basic unfamiliarity with the case. Considerations such as these influenced the $W$ ord court to compel the petitioner to bring habeas corpus in the sentencing state.

The George court, of course, was faced with the same problems. Its response was to rely upon the willingness of confining authorities to defend the foreign conviction and upon the ability of the sentencing state to defend in the confining state, if necessary. The court said, "If the California warden does not wish to defend the North Carolina conviction he can call upon the authorities of North Carolina to provide

56 See text accompanying note 58 infra. 
that defense." 57

That the warden of the confining state, in all likelihood, would not defend against the petition was recognized by the Fourth Circuit. The warden has given effect to the detainer at the request of the foreign state, not his own. It is the judgment and unserved sentence of the foreign state which are under attack, and which are properly defended by the foreign state's attorney general. The evidence and witnesses (except the prisoner) are to be found in the other state; and it is the foreign state which is chiefly concerned with the outcome. ${ }^{68}$ However, if the foreign state does not defend when called, and if the court cannot obtain jurisdiction over the proper authorities in that state, the court probably will dispense only limited relief. Assuming that the district court in the confining state will be reluctant to invalidate the future sentence, it might limit the order to directing the warden to give no effect to the detainer. ${ }^{59}$ On the other hand, if jurisdiction over the other state's officials is assumed through the dual authority fiction and the "agency" of the confining warden, broader relief, although possible, is not desirable. ${ }^{60}$

In order to achieve complete relief, therefore, the petitioner must seek a forum in the sentencing state. However, because of the controversy currently brewing over the applicability of the Ahrens rule to the question of territorial jurisdiction, an unfortunate petitioner may find that the sentencing state lies within a circuit considering itself bound by a broad reading of Ahrens. ${ }^{\text {BI }}$ In that event the petitioner would be rebuffed and told to seek relief in the confining state.

In the confining state, eliminating the detainer might have an immediate impact, reducing the severity of the petitioner's present level of custody; but it would not affect the eventual service of the allegedly invalid future sentence. Since the primary purpose of the petitioner is to avoid serving that sentence if it is invalid, the petitioner should be permitted to bring his habeas corpus action in a federal court in the sentencing state, where the court will clearly have the power to adjudicate the constitutional claims. Otherwise, the prisoner will probably receive only partial relief in the confining state. ${ }^{82}$

57410 F.2d 1179, 1181 (9th Cir. 1969).

58406 F.2d at 355.

09 Id. at 357 n.6. Even if the court ordered that the warden give no effect to the detainer, it would not necessarily follow that the warden must somehow change the status of the prisoner. Perhaps it might be the warden's judgment that the prisoner's demeanor still requires that he be held in maximum security. Whether under these circumstances a prisoner has a further remedy remains doubtful. See note 34 stipra.

60 See text accompanying notes $56-57$ supra.

61 This availability of a complete remedy depends, of course, upon whether the district court in the sentencing state considers itself bound by Ahrens or by a decision of its court of appeals. See, e.g., Hearne v. Washington State Parole Bd., 300 F. Supp. 536 (E.D. Wash. 1969). See also cases cited note 48 supra.

62 But see 406 F.2d at 365 (Sobeloff, J., dissenting). 


\section{Conclusion}

The Word decision is an attempt to afford a prisoner prompt adjudication of alleged violations of his constitutional rights in the forum most capable of providing a fair determination of his claim. In reaching its result, the court chose to disregard certain habeas corpus doctrines unresponsive to the needs of the law in its present state of development. The Fourth Circuit thus offers a model decision expanding the scope of federal habeas corpus, a development which the other circuits should be encouraged to recognize. 